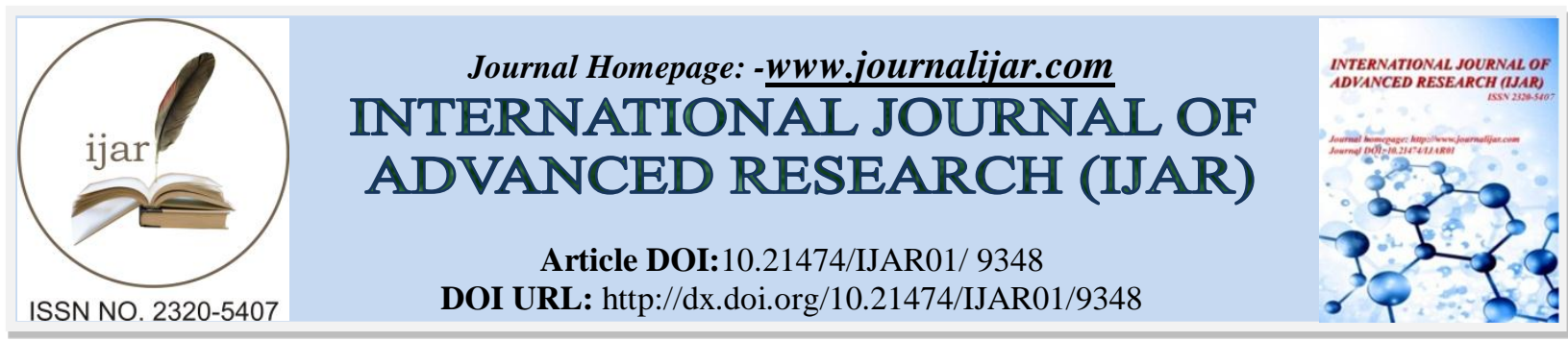

RESEARCH ARTICLE

\title{
ANTIDIABETIC EFFECT OF CONYZA AEGYPTIACA (L.) DRYAND EX. AITON IS IMPROVED BY SWIMMING IN RAT.
}

\section{Baï Huguette Akakpo ${ }^{1,2}$, Casimir Dewanou Akpovi ${ }^{3}$, Judith Fifamin Ahounou Aïkpé ${ }^{1}$, Mansourou} Moudachirou $^{2}$, Joachim Djimon Gbénou ${ }^{2}$ and Pierre Houndjovi Dansou ${ }^{1}$.

1. Laboratory of Effort Physiology, National Institute of Youth, Physical and Sport Education, University of Abomey-Calavi, 01 Po. Box 169 Porto-Novo, Republic of Benin.

2. Laboratory of Pharmacognosy and Essential Oils, Faculty of Sciences and Techniques University of AbomeyCalavi, 01 Po. Box 918 Cotonou, Republic of Benin.

3. Research Laboratory in Applied Biology, Polytechnic School of Abomey-Calavi, University of Abomey-Calavi, 01 Po. Box 2009 Abomey-Calavi, Benin.

\section{Manuscript Info}

\section{Manuscript History}

Received: 05 May 2019

Final Accepted: 07 June 2019

Published: July 2019

Key words:-

Conyza aegyptiaca, diabetes, physical activity, rat, Benin.

\section{Abstract}

Conyza aegyptiaca (C. aegyptiaca) is one medicinal plant used for the treatment of diabetes by African populations. We showed previously that $\mathrm{C}$. aegyptiaca is not toxic in rats, prevents hepatic glucose release and has anti-hyperglycemic properties. In addition to medical treatment, clinicians recommend the practice of Sport and Physical Activity (SPA) in diabetics.

Objective: To determine C. aegyptiaca extracts anti-diabetic effect alone and with SPA in streptozotocin-induced diabetic rats.

Methods: Serum glucose, aspartate aminotransferase (AST) and alanine aminotransferase (ALT) transaminases, total cholesterol (TC), triglycerides (TG), HDL-cholesterol (HDL-C), LDL-cholesterol (LDLC), Creatinine (Creat.), potassium $\left(\mathrm{K}^{+}\right)$, chloride $\left(\mathrm{Cl}^{-}\right)$, sodium $\left(\mathrm{Na}^{+}\right)$, calcium $\left(\mathrm{Ca}^{2+}\right)$ and magnesium $\left(\mathrm{Mg}^{2+}\right)$ were measured using ELITech reagents.

Results: C. aegyptiaca extracts decreased significantly glucose level in diabetic rats compared to control. SPA induced a further decrease in blood glucose in the group treated with Eth. Ext. $(\mathrm{p}=0.045)$. In diabetic rats without treatment, SPA induced a significant decrease in blood glucose on day $14(\mathrm{p}=0.047)$ compared to untrained rats. C. aegyptiaca extracts combined with SPA significantly decreased Creat. ( $\mathrm{p}=0.008)$, ASAT ( $\mathrm{p}=0.0007)$, ALT $(\mathrm{p}=0.045)$, LDL-C $(\mathrm{p}=0.01), \mathrm{TG}(\mathrm{p}=0.007)$, CT $(\mathrm{p}=0.045)$ and increased HDL-C $(\mathrm{p}=0.008), \mathrm{Na}^{+}(\mathrm{p}=0.047)$ level in diabetic rats compared to untrained diabetic. Conclusion: Our results suggest that C. aegyptiaca has greater antidiabetic properties when aqueous extracted, and the practice of SPA improves these properties. 


\section{Introduction:-}

Diabetes mellitus (DM) is a metabolic disorder characterized by hyperglycemia due to defection of insulin secretion, insulin action or both (Goldenberg and Punthakee, 2013; Hussain et al., 2007). The prevalence of DM is increasing across the world (World Health Organisation, 2016). Type 2 diabetes (T2D) is one of the major public health challenges of the 21 st century. Overweight, sedentary lifestyle and dietary components are risk factors but also central themes for prevention (Hussain et al., 2007). Regular physical activity reduces the risk of T2D in adults by 20-60\% in a dose response manner (Hussain et al., 2007; Vuori, 2001).

Because of the high cost of conventional anti-diabetic drugs (Gning et al., 2007), traditional treatment based on plants becomes an alternative option for financially poor populations who may have problems of accessibility to modern drugs. To overcome diabetes, physical activity practice is recommended (World Health Organisation, 2016). For these reasons, the development of new therapies from plants that are able to control diabetes mellitus is of great interest.

Several medicinal plants have been found to be successful in diabetes treatment and some have been tested and their active compounds identified (Grover et al., 2002). This has led researchers to intensify research of suitable treatment from plant origin for diabetes care. Conyza aegyptiaca (L.) Dryand ex. Aiton, belonging to the Asteraceae family, is a well-known plant used by the population of Togo and Benin (West Africa). Also called EGBE VEVE in Mina (local dialect), Conyza aegyptiaca (C. aegyptiaca) is widely used to overcome malaria, sickle cell disease, and sore throat (Akpagana et al., 1996). Recently, an ethnobotanic study found that this plant is also used for obesity and diabetes treatment by West African populations (Gbekley et al., 2015).

The anti-diabetic effect attributed to medicinal plants is generally reflected in their efficacy on inhibition of intestinal absorption, stimulation of insulin secretion by the pancreas, inhibition of glucose production by the liver or stimulation of the storage of blood glucose by the liver and muscles (Hanan and Mona, 2014). More ever, physical exercise reduced body weight, visceral fat accumulation (Irwin et al., 2003; Ross et al., 2000), insulin resistance (Kelley and Goodpaster, 1999; Rice et al., 1999), improved glucose tolerance (Dengel et al., 1998; Kelley and Goodpaster, 1999) and normalized lipid profile (Kraus et al., 2002; Rice et al., 1999).

In previous study, we showed that C. aegyptiaca extracts prevent liver glucose liberation in vitro (Akakpo et al., 2016), thus promoting glucose storage in liver. We also showed that C. aegyptiaca aerial parts extracts is safe and has antihyperglycemia potential as it normalized induced high blood glucose level without causing hypoglycemia (Akakpo et al., 2017). Here, we tested the antidiabetic effect of C. aegyptiaca alone and in association with forced swimming on streptozotocin-induced diabetes rats.

\section{Materials and Methods:- Plant material:}

The plant material was composed of the aerial parts of C. aegyptiaca. The leaves and stem of the plant were shadedried and ground into a fine powder. The powder was then extracted with water and ethanol.

\section{Extraction:}

For the aqueous extraction, decoction was done on a heating plate during 30 minutes by addition of $1000 \mathrm{ml}$ distilled water to $100 \mathrm{~g}$ of powder. The mixture was filtered with Whitman paper and evaporated under rota vapor at 65$70^{\circ} \mathrm{C}$. The ethanolic extraction was done by macerating $100 \mathrm{~g}$ of powder in ethanol diluted at $50^{\circ}$ with distilled water, during 24 hours mixed by homogenizer. After filtration with Whitman paper, the product was evaporated with the rota vapor at $40-45^{\circ} \mathrm{C}$. Extracts were conserved at $4{ }^{\circ} \mathrm{C}$.

\section{Animal material:}

Male and female albinos Wistar rats weighing 200 to $250 \mathrm{~g}$ at the age of eight to ten weeks were used for the study. Animals were housed in polypropylene cages and maintained under standard conditions with an alternated cycle of twelve hours light and twelve hours dark. They had free access to food and water. Room temperature was maintained at $25^{\circ} \mathrm{C}$ with a relative humidity of $35-60 \%$. 


\section{Antidiabetic activity:}

To induce diabetes, the rats were administered nicotinamide (NAD) $230 \mathrm{mg} / \mathrm{kg}$ (ip) $15 \mathrm{~min}$ before streptozotocin (STZ) $65 \mathrm{mg} / \mathrm{kg}$ (iv) after $16 \mathrm{~h}$ fasting (Masiello et al., 1998; Srinivasan and Ramarao, 2007). Seventy two hours later, rats were classified diabetics if glucose level $\geq 175 \mathrm{mg} / \mathrm{dl}$. Animals were divided into 5 groups of 2 females and 3 males each. Group 1 received Glibenclamide $10 \mathrm{mg} / \mathrm{kg}$ bw, groups 2 and 3 received aqueous and ethanolic extract at $500 \mathrm{mg} / \mathrm{kg}$ bw of C. aegyptiaca respectively, group 4 (diabetics without treatment) and group 5 (non-diabetic) received only distilled water at $10 \mathrm{ml} / \mathrm{kg}$ bw, once a day during 14 days.

Blood parameters were measured before diabetes induction (D0) and at D14. Serum glucose was measured by Glucose Oxidase (GOD-POD) method (ELITech Group, Puteaux, France) according to the manufacturer's instructions. Aspartate amino transferase (AST) and alanine amino transferase (ALT) levels were measured using an automated blood analyzer Hitachi 705 (Hitachi, Japan), with DiaSys (Diagnostic Systems GmbH, Germany) reagents. Serum levels of total cholesterol (TC), triglycerides (TG), HDL-cholesterol (HDL-C), LDL-cholesterol (LDL-C), creatinine (Creat.), potassium $\left(\mathrm{K}^{+}\right)$, chloride $\left(\mathrm{Cl}^{-}\right)$, sodium $\left(\mathrm{Na}^{+}\right)$, calcium $\left(\mathrm{Ca}^{2+}\right)$ and magnesium $\left(\mathrm{Mg}^{2+}\right)$ were measured using Elitech reagents (ELITech Group, Maizy, France).

\section{Antidiabetic activity associated with sport and physical activity:}

Rats were submitted to swimming during 28 days (Table 1) (Association Canadienne du Diabète, 2008; Snowling NJ, 2006). The swimming was performed in a glass jar $(90 \mathrm{~cm} \times 50 \mathrm{~cm} \times 50 \mathrm{~cm})$ filled with water up to $35 \mathrm{~cm}$ (Kamakura et al., 2001; Matsumoto et al., 1996). Five groups of five rats each were used in this study and biochemical parameters were measured at D7, D14, D21 and D28.

\section{Statistical analysis:}

Data are expressed as mean \pm standard error of the mean (SEM) and evaluated by Student's t-test using SigmaPlot statistical analysis software 2014 (Systat Software, Inc. San Jose, CA, USA). A level of p <0.05 was set as significant.

\section{Results:-}

\section{Antidiabetic activity:}

Figure 1 showed variation of glucose level in diabetic rats. The first day of treatment (Day 1), glucose level significantly increased compared to D0 $(\mathrm{p}=0.0009)$. In diabetic rats without treatment, glucose level remained significantly high during the experience $(\mathrm{p}=0.0460)$ compared to treated groups. At $\mathrm{D} 7$, glucose level significantly decreased in ethanolic extract group ( $\mathrm{p}=0.0450)$, in aqueous extract group $(\mathrm{p}=0.0031)$ and in Glibenclamide group $(\mathrm{p}=0.0046)$. The decrease remained until D14 (Fig.1).

Creatinine level did not change in all groups. In contrast, the level of the enzyme AST significantly decreased in group treated with $\mathrm{C}$. aegyptiaca aqueous extracts $(\mathrm{p}=0.0007)$, Glibenclamide treated group $(\mathrm{p}=0.0009)$ and ethanolic treated group $(\mathrm{p}=0.0047)$ compared to D0. The level of the enzyme ALT also significantly decreased respectively in diabetic without treatment group $(\mathrm{p}=0.0091)$ and in Glibenclamide treated group $(\mathrm{p}=0.0046)$ (Table 2).

Aqueous and ethanolic extracts had no significant effect on TC and TG. However, LDL-C level significantly decreased in aqueous extract group ( $\mathrm{p}=0.0472)$ whereas HDL-C level significantly increased $(\mathrm{p}=0.0481)$ at D14 compared to D0 (Table 4). In the group of rats taken Glibenclamide $10 \mathrm{mg} / \mathrm{kg}$, triglycerides $(\mathrm{p}=0.0471)$ and LDL-C $(\mathrm{p}=0.0009)$ levels significantly decreased whereas HDL-C $(\mathrm{p}=0.0009)$ level significantly increased (Table 3$)$.

Rats treated with aqueous extract showed a significant increased level of potassium $(\mathrm{p}=0.0471)$ and sodium $(\mathrm{p}=0.0092)$. Only potassium level significantly increased in group of ethanolic extract $(\mathrm{p}=0.0046)$. Calcium, chloride and magnesium levels did not change in any group (Table 5). No variation in electrolytes levels was recorded in normal rats. In contrast, diabetic rats without treatment showed significant potassium and sodium levels increase $(\mathrm{p}=0.0451)($ Table 4$)$.

\section{Antidiabetic effect of $\mathrm{C}$. aegyptiaca combined with sport and physical activity:}

Aqueous extract $500 \mathrm{mg} / \mathrm{kg}$ bw ( $\mathrm{p}=0.0091$ ) and Glibenclamide $10 \mathrm{mg} / \mathrm{kg}(\mathrm{p}=0.0046)$ significantly decreased glucose level at D7 (Fig. 2A). The association of Sport and Physical Activity (SPA) to C. aegyptiaca aqueous extract and Glibenclamide did not induce additional glucose level variation. In ethanolic extract group however, SPA caused further glucose level decrease ( $\mathrm{p}=0.0450$ ) (Fig. 2A). Glucose level was unchanged in normal rats submitted to SPA 
or not (Fig. 2B). Glucose level was significantly decreased in diabetic rats submitted to SPA alone at D7 ( $\mathrm{p}=0.0080$ ) and D14 ( $\mathrm{p}=0.0470)$ compared to diabetic rats without SPA at D7 and D14 (Fig. 2B).

Table 5 showed results of the combined effect of C. aegyptiaca and SPA on liver and kidney function. The practice of swimming showed an additive decreasing effect on creatinine level in the aqueous extract taken groups of rats $(\mathrm{p}=0.0092)$ and in diabetic rats without treatment $(\mathrm{p}=0.0461)$.

Physical activity alone decreased TG $(\mathrm{p}=0.0008), \mathrm{TC}(\mathrm{p}=0.0009)$ and LDL-C ( $\mathrm{p}=0.0007)$, but increased HDL-C level $(\mathrm{p}=0.0491)$ in diabetic without treatment. Combined to extracts and Glibenclamide, physical activity decreased TG $(p=0.0070), T C(p=0.0450)$, LDL-C $(p=0.0070)$, but increased HDL-C level $(p=0.0080)$ (Table 6).

Physical activity increased $\mathrm{Na}^{+}(\mathrm{p}=0.0451), \mathrm{Cl}^{-}(\mathrm{p}=0.0091)$ but decreased $\mathrm{Ca}^{2+}(\mathrm{p}=0.0091)$ levels in diabetic without treatment group compared to diabetic group without SPA. Aqueous extract and SPA together increased $\mathrm{Na}^{+}$level $(\mathrm{p}=0.0470)$ but showed no effect on $\mathrm{Cl}^{-}, \mathrm{Mg}^{2+}$ and $\mathrm{Ca}^{2+}$ levels. Glibenclamide and SPA combined increased all tested electrolyte level (Table 7).

\section{Discussion:-}

C. aegyptiaca (L.) Dryand ex. Aiton is a widely used plant to treat malaria, gonorrhoea (Goldenberg and Punthakee, 2013), and cardiovascular diseases (Hussain et al., 2007). It was recently reported that this plant treats diabetes (World Health Organisation, 2016). However, the use of C. aegyptiaca to treat diseases is based on empirical knowledge, with no scientific basis (Vuori, 2001), as is the case for most of medicinal plants in Africa. World Health Organization (Gning et al., 2007) promotes ethnobotanic studies and pharmaceutical research to improve disease treatment based on medicinal plants.

In our previous work, we showed that $\mathrm{C}$. aegyptiaca displayed inhibitory properties of hepatic release of glucose (World Health Organisation, 2016) and possesses anti-hyperglycemic effects (Grover et al., 2002) in rats. In this study, we analyzed the antidiabetic properties of C. aegyptiaca alone and when combined with SPA. Our results showed that $\mathrm{C}$. aegyptiaca extracts induce a significant decrease in blood glucose levels in diabetic rats compared to untreated diabetic rats at a level comparable to Glibenclamide, an antidiabetic molecule used as a reference in this study. This finding confirms the anti-hyperglycemic properties we showed earlier (Grover et al., 2002) and supports the empirical knowledge that C. aegyptiaca treats diabetes (World Health Organisation, 2016). C. aegyptiaca contains alkaloids and flavonoids (Akakpo et al., 2016) that are involved in stimulating insulin secretion (Sharma et al., 2008). SPA alone significantly lowered blood glucose levels in diabetic rats at a level similar to ethanolic extract but less than aqueous extracts. A further decrease in blood glucose was observed when SPA was associated with the ethanolic extract. The combination of SPA with the aqueous extract did not induce any further drop in blood glucose. These results suggest that SPA produces an additive effect on the C. aegyptiaca-induced blood glucose lowering.

Regular physical activity lowers blood glucose, decreases body fat, improves lipid balance, and generally helps control T2D risk factors and prevent its complications (Akpagana et al., 1996; Gbekley et al., 2015; Hanan and Mona, 2014). Since C. aegyptiaca blocks the hepatic release of glucose (Akakpo et al., 2016) and normalizes hyperglycemia induced in rats (Akakpo et al., 2017), the additive effect observed can be explained by the greater use of glucose during effort.

Our results showed a significant decrease in blood creatinine levels in diabetic rats subjected to SPA. During effort, blood drained by organs like kidneys decreases in favor of muscles and induces decreases in creatinine level (Rice et al., 1999; Ross et al., 2000). Decrease in blood creatinine level and other parameters such as glomerular filtration rate at the end of exercise is transient and reversed approximately 24 hours later (Ross et al., 2000). SPA did not produce an additive effect on transaminases levels reached with $\mathrm{C}$. aegyptiaca extracts and Glibenclamide. These results show that C. aegyptiaca has hepatoprotective properties (World Health Organisation, 2016) that SPA obviously does not influence. Altered lipid parameters may lead to atherosclerosis and coronary heart disease (Kelley and Goodpaster, 1999). CT, TG and LDL-C levels are reported higher in diabetic patients compared to nondiabetic controls (Kraus et al., 2002; Akpovi et al., 2015). As in the case of blood glucose, we observed an additive effect of C. aegyptiaca and SPA in the normalization of disturbed lipid profile in diabetic rats. This result supports the idea that regular SPA reduces fat mass and improves lipid balance (Akpagana et al., 1996). SPA also promotes muscle use of free fatty acids by increasing the number of mitochondria and mitochondria enzymes involved in beta- 
oxidation (Akakpo et al., 2016). Our study is the first to show that C. aegyptiaca reverses disturbed lipid profile in streptozotocin-induced diabetic rat.

Numerous studies have reported a wide variety of electrolyte disorders in diabetics (Akakpo et al., 2017; Yessoufou et al., 2013; Srinivasan and Ramarao, 2007; Prashanth et al., 2001). In this study, we measured a significant increase in $\mathrm{K}^{+}$and $\mathrm{Na}^{+}$in diabetic rats compared to control, while $\mathrm{Ca}^{2+}, \mathrm{Cl}^{-}$and $\mathrm{Mg}^{2+}$ remained unchanged. High levels of $\mathrm{K}^{+}$ are reported in diabetic rats (Prashanth et al., 2001). Chronic hyperkalemia in diabetes was reported to be associated with hypoaldosteronism syndrome and the reduction of tubular $\mathrm{K}^{+}$secretion (Liamis et al., 2012). In this syndrome, patients generally have asymptomatic hyperkalemia characterized by mild to moderate renal impairment (Prashanth et al., 2001). Since glucose is an osmotically active substance, hyperglycemia increases serum osmolarity, draining excess fluid out of the cells in favors of blood circulation. This leads to a reduction in serum $\mathrm{Na}^{+}$levels by hemodilution and hyponatremia (Masiello et al., 1998).

In this study, we showed that SPA significantly improves the electrolytes profile in both diabetic rats and nondiabetic control rats. This effect of SPA is independent of C. aegyptiaca extracts. Physical exercise and nutrition are the cornerstones of the diabetes prevention mechanism. In healthy individuals and animals, physical activity alone can delay or even prevent the development of T2D later in life. Results showed here suggest that the antidiabetic effect of C. aegyptiaca extracts are mainly due to their antioxidant properties (Akakpo et al., 2016). SPA enhances the activity of antioxidant enzymes in diabetic rats subjected to swimming (Vogiatzi et al., 2009). In doing so, SPA potentiates the antidiabetic effect of $\mathrm{C}$. aegyptiaca extracts by strengthening the body's defense against very harmful oxidative stress in diabetics (Rakieten et al., 1963).

In conclusion, we showed that streptozotocin-induced diabetes in albino Wistar rats is accompanied by hyperglycemia, an imbalance in blood electrolyte levels, and dyslipidemia characterized by high levels of CT and TG and impaired kidneys and liver function. All these disturbances were substantially corrected by C. aegyptiaca extracts. SPA alone reduced blood glucose levels and lipid parameters CT and TG without reaching normal levels. However, the combination of SPA with C. aegyptiaca extracts further reduced levels of disturbed parameters in diabetic rats. Together, our results showed that SPA potentiates the antidiabetic effect of C. aegyptiaca extracts.

\section{Authors' contributions:}

B. Huguette Akakpo is a $\mathrm{PhD}$ student who conducts the experiences, treats data and writes the manuscript. She also co-finances the study.

Casimir D. Akpovi is an Associate Professor of Biochemistry and Physiology at the University of Abomey-Calavi. He helps the student financially and makes first corrections of the manuscript and its review.

Judith F. Ahounou Aikpé, Associate Professor of Effort Physiology at the University of Abomey-Calavi, contributes to the manuscript writing and editing.

Mansourou Moudachirou, Emeritus Professor of Chemistry of University of Abomey Calavi, advises the student when necessary. He also contributes to the manuscript editing.

Joachim D. Gbénou, Full Professor of Chemistry of University of Abomey Calavi, co-supervises the study and contributes to the study design and manuscript editing.

Pierre H. Dansou, Full Professor of Effort Physioloy of University of Abomey Calavi, supervises the study and contributes to the study design and manuscript editing.

\section{Conflicts of interest:}

No potential conflict of interest was reported by the authors.

\section{Acknowledgements:-}

The authors are grateful to Professor Anatole Laleye (Laboratoire de Cytogénétique et de Biologie Moléculaire, Faculté des Sciences de la Santé, Université d'Abomey-Calavi, Bénin) for kindly providing the Nicotinamide. The authors are grateful to Doctor Fidèle Assogba (Laboratoire de Pharmacognossie et des Huiles essentielles, Université d'Abomey-Calavi, Cotonou, Bénin) for his technical assistance and the manuscript review. 
Table 1:-Swimming schedule

\begin{tabular}{|c|l|l|l|l|l|l|l|}
\hline & Monday & Tuesday & Wednesday & Thirday & Friday & Saturday & Sunday \\
\hline Week 1 & LF-feed & $\begin{array}{l}\text { F-feedS } \\
(30 \mathrm{~min})\end{array}$ & $\begin{array}{l}\text { F-feedS } \\
(30 \mathrm{~min})\end{array}$ & $\begin{array}{l}\text { F-feedS } \\
(30 \mathrm{~min})\end{array}$ & $\begin{array}{l}\text { F-feedS } \\
(30 \mathrm{~min})\end{array}$ & $\begin{array}{l}\text { F-feedS } \\
(30 \mathrm{~min})\end{array}$ & $\begin{array}{l}\text { F-feedPF } \\
12 \mathrm{~h}\end{array}$ \\
\hline Week 2 & LF-feed & $\begin{array}{l}\text { F-feedS } \\
(40 \mathrm{~min})\end{array}$ & $\begin{array}{l}\text { F-feedS } \\
(40 \mathrm{~min})\end{array}$ & $\begin{array}{l}\text { F-feedS } \\
(40 \mathrm{~min})\end{array}$ & $\begin{array}{l}\text { F-feedS } \\
(40 \mathrm{~min})\end{array}$ & $\begin{array}{l}\text { F-feedS } \\
(40 \mathrm{~min})\end{array}$ & $\begin{array}{l}\text { F-feedPF } \\
12 \mathrm{~h}\end{array}$ \\
\hline Week 3 & LF-feed & $\begin{array}{l}\text {-feedS } \\
(50 \mathrm{~min})\end{array}$ & $\begin{array}{l}\text { F-feedS } \\
(50 \mathrm{~min})\end{array}$ & $\begin{array}{l}\text { F-feedS } \\
(50 \mathrm{~min})\end{array}$ & $\begin{array}{l}\text { F-feedS } \\
(50 \mathrm{~min})\end{array}$ & $\begin{array}{l}\text { F-feedS } \\
(50 \mathrm{~min})\end{array}$ & $\begin{array}{l}\text { F-feedPF } \\
12 \mathrm{~h}\end{array}$ \\
\hline Week 4 & LF-feed & $\begin{array}{l}\text { F-feedS } \\
(60 \mathrm{~min})\end{array}$ & $\begin{array}{l}\text { F-feedS } \\
(60 \mathrm{~min})\end{array}$ & $\begin{array}{l}\text { F-feedS } \\
(60 \mathrm{~min})\end{array}$ & $\begin{array}{l}\text { F-feedS } \\
(60 \mathrm{~min})\end{array}$ & $\begin{array}{l}\text { F-feedS } \\
(60 \mathrm{~min})\end{array}$ & $\begin{array}{l}\text { F-feedPF } \\
12 \mathrm{~h}\end{array}$ \\
\hline
\end{tabular}

LF-feed: Levy Force-feeding; F-feedS: Force-feeding Swimming; F-feed: Force-feeding; F-feedPF: Force-feeding Pause Fasting

Table 2:-Conyza aegyptiaca effect on liver and kidney profile of diabetic rats

\begin{tabular}{|c|c|c|c|c|c|}
\hline & $\mathrm{TC}(\mathrm{g} / \mathrm{L})$ & TG (g/L) & HDL-C $(\mathrm{g} / \mathrm{L})$ & LDL-C $(\mathrm{g} / \mathrm{L})$ \\
\hline \multirow{2}{*}{$\begin{array}{l}\text { Normal without } \\
\text { treat. }\end{array}$} & D0 & $0.77 \pm 0.03$ & $0.68 \pm 0.01$ & $0.44 \pm 0.06$ & $0.27 \pm 0.05$ \\
\hline & D14 & $0.78 \pm 0.01$ & $0.66 \pm 0.03$ & $0.45 \pm 0.01$ & $0.28 \pm 0.01$ \\
\hline \multirow{2}{*}{$\begin{array}{l}\text { Diabetic without } \\
\text { Treat. }\end{array}$} & D0 & $0.77 \pm 0.03$ & $0.71 \pm 0.07$ & $0.36 \pm 0.03$ & $0.25 \pm 0.01$ \\
\hline & D14 & $1.62 \pm 0.01 * *$ & $1.19 \pm 0.12 * *$ & $0.28 \pm 0.02 * *$ & $0.79 \pm 0.03^{+++}$ \\
\hline \multirow[t]{2}{*}{ Aq. Ext. $500 \mathrm{mg} / \mathrm{kg}$} & D0 & $0.75 \pm 0.17$ & $0.61 \pm 0.09$ & $0.37 \pm 0.04$ & $0.28 \pm 0.14$ \\
\hline & D14 & $0.66 \pm 0.12$ & $0.69 \pm 0.07$ & $0.49 \pm 0.07^{*}$ & $0.21 \pm 0.02^{*}$ \\
\hline \multirow[t]{2}{*}{ Eth. Ext. $500 \mathrm{mg} / \mathrm{kg}$} & D0 & $0.72 \pm 0.12$ & $0.69 \pm 0.07$ & $0.39 \pm 0.07$ & $0.27 \pm 0.02$ \\
\hline & D14 & $0.67 \pm 0.07$ & $0.57 \pm 0.10$ & $0.42 \pm 0.04$ & $0.26 \pm 0.01$ \\
\hline \multirow{2}{*}{$\begin{array}{l}\text { Glibenclamide } 10 \\
\mathrm{mg} / \mathrm{kg}\end{array}$} & D0 & $0.74 \pm 0.11$ & $0.63 \pm 0.09$ & $0.34 \pm 0.02$ & $0.32 \pm 0.04$ \\
\hline & D14 & $0.65 \pm 0.02$ & $0.39 \pm 0.02 *$ & $0.45 \pm 0.11^{+}$ & $0.19 \pm 0.04^{++}$ \\
\hline
\end{tabular}

Values are mean \pm SEM of 5 independent experiences $(n=5)$; Aq. Ext.: Aqueous extract; Eth. Ext.: Ethanolic extract; AST: Aspartate AminoTransferase; ALT: Alanine Amino-Transferase; Diabetics without Treat.: Diabetics without Treatment; Normal without Treat.: Normal without Treatment. *p $<0.05 ; * * p<0.005 ;+p<0.01 ;++p<0.001$. Results of D14 compared to D0 into the same group.

Table 3:- Conyza aegyptiaca effect on lipid profile of diabetic rats

\begin{tabular}{|l|l|r|r|r|}
\hline \multicolumn{2}{|l|}{} & Creatinine $(\mathrm{mg} / \mathrm{L})$ & AST (UI/L) & ALT (UI/L) \\
\hline Normal without treat. & D0 & $8.64 \pm 0.26$ & $100.21 \pm 2.50$ & $35.51 \pm 1.01$ \\
& D14 & $7.75 \pm 0.35$ & $97.21 \pm 8.07$ & $35.49 \pm 1.10$ \\
\hline Diabetic without treat. & D0 & $13.42 \pm 0.44$ & $197.72 \pm 7.91$ & $87.90 \pm 1.76$ \\
& D14 & $12.57 \pm 0.87$ & $154.75 \pm 11.3^{+}$ & $55.05 \pm 16.28^{+}$ \\
\hline Aq. Ext. 500 mg/kg & D0 & $13.60 \pm 0.24$ & $220.57 \pm 3.54$ & $82.95 \pm 7.37$ \\
& D14 & $11.52 \pm 0.77$ & $137.09 \pm 14.71^{++}$ & $45.40 \pm 8.28^{*}$ \\
\hline Eth. Ext. $500 \mathrm{mg} / \mathrm{kg}$ & D0 & $12.76 \pm 0.09$ & $196.21 \pm 7.87$ & $84.55 \pm 3.29$ \\
& D14 & $12.09 \pm 0.95$ & $122.71 \pm 4.95^{* *}$ & $66.78 \pm 10.66$ \\
\hline Glibenclamide & D0 & $13.24 \pm 0.33$ & $192.72 \pm 5.88$ & $83.86 \pm 5.88$ \\
$10 \mathrm{mg} / \mathrm{kg}$ & D14 & $10.35 \pm 0.32$ & $102.31 \pm 8.06^{++}$ & $55.00 \pm 8.07^{* *}$ \\
\hline
\end{tabular}

Values are mean \pm SEM of 5 independent experiences $(n=5)$; Aq. Ext.: Aqueous extract; Eth. Ext.: Ethanolic extract; Diabetics without Treat.: Diabetics without Treatment. TC: Total cholesterol; TG: Triglycerides; HDL-cholesterol (HDL-C); LDL-cholesterol $($ LDL-C); $+\mathrm{p}<0.01$; ${ }^{++} \mathrm{p}<0.0001 ;{ }^{++} \mathrm{p}<0.001 ;{ }^{*} \mathrm{p}<0.05 ;{ }^{* *} \mathrm{p}<0.005$. Results of D14 compared to D0 into the same group. 
Table 4:-Conyza aegyptiaca effect on electrolytic profile of diabetic rats

\begin{tabular}{|c|c|c|c|c|c|}
\hline & Time & Activity & Creatinine mg/L) & AST (UI/L) & ALT (UI/L) \\
\hline \multirow{3}{*}{$\begin{array}{l}\text { Normal } \\
\text { without Treat. }\end{array}$} & \multicolumn{2}{|l|}{ D0 } & $8.64 \pm 0.26$ & $100.21 \pm 2.50$ & $35.51 \pm 1.01$ \\
\hline & \multirow[b]{2}{*}{ D14 } & SPA- & $7.75 \pm 0.35$ & $97.21 \pm 8.07$ & $35.49 \pm 1.10$ \\
\hline & & $\mathrm{SPA}+$ & $8.12 \pm 0.51$ & $123.37 \pm 17.89$ & $37.98 \pm 1.98$ \\
\hline \multirow{3}{*}{$\begin{array}{l}\text { Diabetic } \\
\text { without Treat. }\end{array}$} & \multicolumn{2}{|l|}{ D0 } & $13.42 \pm 0.44$ & $197.72 \pm 7.91$ & $87.90 \pm 1.76$ \\
\hline & \multirow[b]{2}{*}{ D14 } & SPA - & $12.57 \pm 0.87$ & $184.75 \pm 11.30$ & $76.05 \pm 16.28$ \\
\hline & & SPA + & $10.12 \pm 0.61 *, b$ & $172.85 \pm 13.09$ & $71.74 \pm 18.71$ \\
\hline \multirow{3}{*}{$\begin{array}{l}\text { Aq. Ext. } 500 \\
\mathrm{mg} / \mathrm{kg}\end{array}$} & \multicolumn{2}{|l|}{ D0 } & $13.60 \pm 0.24$ & $220.57 \pm 3.54$ & $82.95 \pm 7.37$ \\
\hline & \multirow[b]{2}{*}{ D14 } & SPA - & $11.52 \pm 0.77$ & $137.09 \pm 14.71^{++}$ & $45.40 \pm 8.28^{+}$ \\
\hline & & SPA + & $10.07 \pm 0.46^{+, b}$ & $153.59 \pm 15.89^{++}$ & $47.09 \pm 13.76^{*}$ \\
\hline \multirow{3}{*}{$\begin{array}{l}\text { Eth. Ext. } 500 \\
\mathrm{mg} / \mathrm{kg}\end{array}$} & \multicolumn{2}{|l|}{ D0 } & $12.76 \pm 0.09$ & $196.21 \pm 7.87$ & $84.55 \pm 3.29$ \\
\hline & \multirow[b]{2}{*}{ D14 } & SPA - & $12.09 \pm 0.95$ & $122.71 \pm 4.95^{* *}$ & $66.78 \pm 10.66$ \\
\hline & & $\mathrm{SPA}+$ & $10.74 \pm 0.96 *$ & $145.49 \pm 12.61 *$ & $85.11 \pm 13.57$ \\
\hline \multirow{3}{*}{$\begin{array}{l}\text { Glibenclamide } \\
10 \mathrm{mg} / \mathrm{kg}\end{array}$} & \multicolumn{2}{|l|}{ D0 } & $13.24 \pm 0.35$ & $192.72 \pm 5.88$ & $83.86 \pm 5.88$ \\
\hline & \multirow[b]{2}{*}{ D14 } & SPA - & $10.35 \pm 0.32$ & $102.31 \pm 8.06^{++}$ & $55.00 \pm 8.07 * *$ \\
\hline & & SPA + & $9.55 \pm 0.89^{+}$ & $95.46 \pm 21.68^{++}$ & $52.23 \pm 12.64^{++}$ \\
\hline
\end{tabular}

Values are mean \pm SEM of 5 independent experiences $(n=5)$; Aq. Ext.: Aqueous extract; Eth. Ext.: Ethanolic extract; Diabetics without Treat.: Diabetics without Treatment. $\mathrm{K}^{+}$: Potassium $; \mathrm{Cl}^{-}:$Chloride ; $\mathrm{Na}^{+}$: Sodium ; $\mathrm{Ca}^{2+}$ : Calcium; $\mathrm{Mg}^{2+}$ : Magnesium; $+\mathrm{p}<0.01 ; * \mathrm{p}<0.05 ; * * \mathrm{p}<0.005$. Results of D14 compared to D0 in same group.

Table 5:-Conyza aegyptiaca and physical activity effect on liver and kidney profile of diabetic rats

\begin{tabular}{|c|c|c|c|c|c|c|}
\hline & Time & Activity & T C (g/L) & TG (g/L) & HDL-C (g/L) & LDL-C (g/L) \\
\hline \multirow{3}{*}{$\begin{array}{l}\text { Normal } \\
\text { without treat. }\end{array}$} & D0 & - & $0.77 \pm 0.03$ & $0.68 \pm 0.01$ & $0.44 \pm 0.06$ & $0.27 \pm 0.05$ \\
\hline & \multirow[b]{2}{*}{ D14 } & SPA - & $0.78 \pm 0.01$ & $0.66 \pm 0.03$ & $0.45 \pm 0.01$ & $0.28 \pm 0.01$ \\
\hline & & SPA + & $0.56 \pm 0.05+$ & $0.50 \pm 0.08^{*}$ & $0.52 \pm 0.02^{\mathrm{a}}$ & $0.21 \pm 0.04 *$ \\
\hline \multirow{3}{*}{$\begin{array}{l}\text { Diabetic } \\
\text { without treat. }\end{array}$} & D0 & - & $0.77 \pm 0.03$ & $0.71 \pm 0.07$ & $0.36 \pm 0.03$ & $0.25 \pm 0.01$ \\
\hline & \multirow[b]{2}{*}{ D14 } & SPA - & $1.62 \pm 0.01 * *$ & $1.19 \pm 0.12 * *$ & $0.28 \pm 0.02 * *$ & $0.79 \pm 0.03^{+++}$ \\
\hline & & SPA + & $0.93 \pm 5.09^{++, a}$ & $0.80 \pm 0.15^{++. a}$ & $0.45 \pm 0.01 * \cdot \mathrm{a}$ & $0.45 \pm 0.01^{++, \mathrm{aa}}$ \\
\hline \multirow{3}{*}{$\begin{array}{l}\text { Aq. Ext. } \\
500 \mathrm{mg} / \mathrm{kg}\end{array}$} & \multicolumn{2}{|l|}{ D0 } & $0.75 \pm 0.17$ & $0.61 \pm 0.09$ & $0.37 \pm 0.04$ & $0.28 \pm 0.14$ \\
\hline & \multirow[b]{2}{*}{ D14 } & SPA - & $0.66 \pm 0.12$ & $0.69 \pm 0.07$ & $0.49 \pm 0.07 *$ & $0.21 \pm 0.02 *$ \\
\hline & & $\mathrm{SPA}+$ & $0.41 \pm 0.09^{*, a}$ & $0.46 \pm 0.05^{*, a}$ & $0.53 \pm 0.05+$ & $0.14 \pm 0.03^{*, b}$ \\
\hline \multirow{3}{*}{$\begin{array}{l}\text { Eth. Ext. } \\
500 \mathrm{mg} / \mathrm{kg}\end{array}$} & \multicolumn{2}{|l|}{ D0 } & $0.72 \pm 0.12$ & $0.69 \pm 0.07$ & $0.39 \pm 0.07$ & $0.27 \pm 0.02$ \\
\hline & \multirow[b]{2}{*}{ D14 } & SPA - & $0.67 \pm 0.07$ & $0.57 \pm 0.10$ & $0.42 \pm 0.04$ & $0.26 \pm 0.01$ \\
\hline & & $\mathrm{SPA}+$ & $0.50 \pm 0.05^{\mathrm{a}}$ & $0.44 \pm 0.04^{b}$ & $0.51 \pm 0.01 *{ }^{b}$ & $0.17 \pm 0.03 *$ \\
\hline \multirow{3}{*}{$\begin{array}{l}\text { Glb } 10 \\
\mathrm{mg} / \mathrm{kg}\end{array}$} & D0 & - & $0.74 \pm 0.11$ & $0.63 \pm 0.09$ & $0.34 \pm 0.02$ & $0.32 \pm 0.04$ \\
\hline & \multirow[b]{2}{*}{ D14 } & SPA - & $0.65 \pm 0.02$ & $0.39 \pm 0.02 *$ & $0.45 \pm 0.11^{+}$ & $0.19 \pm 0.04^{++}$ \\
\hline & & $\mathrm{SPA}+$ & $0.44 \pm 0.03^{* \cdot a}$ & $0.43 \pm 0.02 *$ & $0.53 \pm 0.03^{++, b}$ & $0.21 \pm 9.27^{+}$ \\
\hline
\end{tabular}

Values are mean \pm SEM of 5 independent experiences $(n=5)$; Aq. Ext.: Aqueous extract; Eth. Ext.: Ethanolic extract; AST: Aspartate AminoTransferase; ALT: Alanine Amino-Transferase; Diabetics without Treat.: Diabetics without Treatment; Normal without Treat.: Normal without Treatment. ${ }^{*} \mathrm{p}<0.05 ;{ }^{*} \mathrm{p}<0.005 ;+\mathrm{p}<0.01 ;{ }^{++} \mathrm{p}<0.001$. Results of D14 compared to D0 into the same group. b: $\mathrm{p}<0.01$, results with SPA compared to without SPA, at J14. 
Table 6:-Conyza aegyptiaca and physical activity effect on lipid profile of diabetic rats

\begin{tabular}{|c|c|c|c|c|c|c|}
\hline & & $\begin{array}{c}\mathrm{Na}^{+} \\
(\mathrm{mmol} / \mathrm{L})\end{array}$ & $\begin{array}{c}\mathrm{K}^{+} \\
(\mathrm{mmol} / \mathrm{L})\end{array}$ & $\begin{array}{c}\mathrm{Cl}^{-} \\
(\mathrm{mmol} / \mathrm{L})\end{array}$ & $\begin{array}{c}\mathrm{Ca}^{2+} \\
(\mathrm{mmol} / \mathrm{L})\end{array}$ & $\begin{array}{c}\mathrm{Mg}^{2+} \\
(\mathrm{mmol} / \mathrm{L})\end{array}$ \\
\hline \multirow{2}{*}{$\begin{array}{l}\text { Normal without } \\
\text { Treat. }\end{array}$} & D0 & $138.60 \pm 0.24$ & $3.86 \pm 0.16$ & $99.60 \pm 0.50$ & $96.69 \pm 0.60$ & $19.77 \pm 0.27$ \\
\hline & D14 & $140.20 \pm 0.48$ & $4.02 \pm 0.03$ & $99.60 \pm 1.46$ & $100.70 \pm 0.83$ & $22.71 \pm 1.76$ \\
\hline \multirow{2}{*}{$\begin{array}{l}\text { Diabetic without } \\
\text { Treat. }\end{array}$} & D0 & $132.80 \pm 0.37$ & $3.82 \pm 0.05$ & $100.00 \pm 0.70$ & $96.60 \pm 0.65$ & $22.35 \pm 0.75$ \\
\hline & D14 & $138.40 \pm 1.83^{*}$ & $6.16 \pm 0.08^{*}$ & $97.20 \pm 0.91$ & $99.06 \pm 0.47$ & $20.25 \pm 1.90$ \\
\hline \multirow{2}{*}{$\begin{array}{l}\text { Aq. Ext. } 500 \\
\mathrm{mg} / \mathrm{kg}\end{array}$} & D0 & $128.40 \pm 1.12$ & $4.02 \pm 0.24$ & $100.60 \pm 1.16$ & $97.30 \pm 0.23$ & $20.66 \pm 0.85$ \\
\hline & D14 & $136.20 \pm 1.35^{+}$ & $5.74 \pm 0.13 *$ & $97.20 \pm 1.11$ & $104.63 \pm 1.56$ & $21.61 \pm 1.72$ \\
\hline \multirow{2}{*}{$\begin{array}{l}\text { Eth. Ext. } 500 \\
\mathrm{mg} / \mathrm{kg}\end{array}$} & D0 & $131.40 \pm 0.60$ & $3.94 \pm 0.14$ & $98.80 \pm 0.80$ & $97.39 \pm 0.26$ & $20.78 \pm 1.32$ \\
\hline & D14 & $135.20 \pm 2.24$ & $5.54 \pm 0.02 * *$ & $99.40 \pm 2.35$ & $103.88 \pm 2.06$ & $20.13 \pm 1.84$ \\
\hline \multirow{2}{*}{$\begin{array}{l}\text { Glibenclamide } \\
10 \mathrm{mg} / \mathrm{kg}\end{array}$} & D0 & $133.20 \pm 1.96$ & $3.80 \pm 0.14$ & $99.80 \pm 0.91$ & $97.31 \pm 0.18$ & $21.28 \pm 0.95$ \\
\hline & D14 & $138.20 \pm 0.58^{*}$ & $5.64 \pm 0.16^{*}$ & $96.80 \pm 0.73$ & $92.35 \pm 18.15$ & $23.46 \pm 2.44$ \\
\hline
\end{tabular}

Values are mean \pm SEM of 5 independent experiences $(n=5)$; Aq. Ext.: Aqueous extract; Eth. Ext.: Ethanolic extract; Diabetics without Treat.: Diabetics without Treatment. TC: Total cholesterol; TG: Triglycerides; HDL-cholesterol (HDL-C); LDL-cholesterol (LDL-C); +p<0.01; ${ }^{++} \mathrm{p}<0.001 ;{ }^{+++} \mathrm{p}<0.0001 ;{ }^{*} \mathrm{p}<0.05 ; * * \mathrm{p}<0.005$. Results of D14 compared to D0 into the same group. a: $\mathrm{p}<0.05$; aa: 0.005 ; et b: $\mathrm{p}<0.01 ;$ results with SPA compared to without SPA, at J14.

Table 7:-Conyza aegyptiaca and physical activity effect on electrolytic profile of diabetic rats

\begin{tabular}{|c|c|c|c|c|c|c|c|}
\hline & Time & Activity & $\begin{array}{c}\mathrm{Na}^{+} \\
(\mathrm{mmol} / \mathrm{L})\end{array}$ & $\begin{array}{c}\mathrm{K}^{+} \\
(\mathrm{mmol} / \mathrm{L})\end{array}$ & $\begin{array}{c}\mathrm{Cl}^{-} \\
(\mathrm{mmol} / \mathrm{L})\end{array}$ & $\begin{array}{c}\mathrm{Ca}^{2+} \\
(\mathrm{mmol} / \mathrm{L})\end{array}$ & $\begin{array}{c}\mathrm{Mg}^{2+} \\
(\mathrm{mmol} / \mathrm{L})\end{array}$ \\
\hline \multirow{3}{*}{$\begin{array}{l}\text { Normal } \\
\text { without } \\
\text { treat. }\end{array}$} & \multicolumn{2}{|l|}{ D0 } & $138.60 \pm 0.24$ & $3.86 \pm 0.16$ & $99.60 \pm 0.50$ & $96.69 \pm 0.60$ & $19.77 \pm 0.27$ \\
\hline & \multirow[b]{2}{*}{ D14 } & SPA - & $140.20 \pm 0.48$ & $4.02 \pm 0.03$ & $99.60 \pm 1.46$ & $100.70 \pm 0.83$ & $22.71 \pm 1.76$ \\
\hline & & SPA + & $139.40 \pm 3.66$ & $4.40 \pm 0.17$ & $101.80 \pm 2.01$ & $97.99 \pm 2.04$ & $21.77 \pm 1.12$ \\
\hline \multirow{3}{*}{$\begin{array}{l}\text { Diabetic } \\
\text { without } \\
\text { treat. }\end{array}$} & D0 & - & $132.80 \pm 0.37$ & $3.82 \pm 0.05$ & $100.00 \pm 0.70$ & $96.60 \pm 0.65$ & $22.35 \pm 0.75$ \\
\hline & \multirow[b]{2}{*}{ D14 } & SPA - & $138.40 \pm 1.83 *$ & $6.16 \pm 0.08^{*}$ & $97.20 \pm 0.91$ & $99.06 \pm 0.47$ & $20.25 \pm 1.90$ \\
\hline & & SPA + & $145.60 \pm 2.13^{+. a}$ & $6.14 \pm 0.28^{*}$ & $107.40 \pm 1.12^{*, b}$ & $95.60 \pm 1.69^{b}$ & $22.84 \pm 1.00$ \\
\hline \multirow{3}{*}{$\begin{array}{l}\text { Aq. Ext. } \\
500 \\
\mathrm{mg} / \mathrm{kg}\end{array}$} & D0 & & $128.40 \pm 1.12$ & $4.02 \pm 0.24$ & $100.60 \pm 1.16$ & $97.30 \pm 0.23$ & $20.66 \pm 0.85$ \\
\hline & \multirow[b]{2}{*}{ D14 } & SPA - & $136.20 \pm 1.35^{+}$ & $5.74 \pm 0.13^{*}$ & $97.20 \pm 1.11$ & $104.63 \pm 1.56$ & $21.61 \pm 1.72$ \\
\hline & & SPA + & $140.00 \pm 2.25^{+, \mathrm{a}}$ & $5.60 \pm 0.24^{+}$ & $107.00 \pm 2.75$ & $97.35 \pm 1.43$ & $24.00 \pm 1.06$ \\
\hline \multirow{3}{*}{$\begin{array}{l}\text { Eth. Ext. } \\
500 \\
\mathrm{mg} / \mathrm{kg}\end{array}$} & D0 & & $131.40 \pm 0.60$ & $3.94 \pm 0.14$ & $98.80 \pm 0.80$ & $97.39 \pm 0.26$ & $20.78 \pm 1.32$ \\
\hline & \multirow[b]{2}{*}{ D14 } & SPA - & $135.20 \pm 2.24$ & $5.54 \pm 0.02 *$ & $99.40 \pm 2.35$ & $103.88 \pm 2.0$ & $20.13 \pm 1.84$ \\
\hline & & SPA + & $135.00 \pm 0.83$ & $5.96 \pm 0.18^{++}$ & $102.20 \pm 2.45$ & $102.51 \pm 3.14$ & $24.62 \pm 1.40$ \\
\hline \multirow{3}{*}{$\begin{array}{l}\text { Glb } 10 \\
\mathrm{mg} / \mathrm{kg}\end{array}$} & D0 & - & $133.20 \pm 1.96$ & $3.80 \pm 0.14$ & $99.80 \pm 0.91$ & $97.31 \pm 0.18$ & $21.28 \pm 0.95$ \\
\hline & \multirow[b]{2}{*}{ D14 } & SPA - & $138.20 \pm 0.58^{*}$ & $5.64 \pm 0.16^{*}$ & $96.80 \pm 0.73$ & $92.35 \pm 18.15$ & $23.46 \pm 2.44$ \\
\hline & & SPA + & $147.60 \pm 1.99^{++}$ & $5.9 \pm 0.17^{++}$ & $104.80 \pm 3.55^{*}$ & $101.58 \pm 2.56$ & $25.57 \pm 0.60^{* *}$ \\
\hline
\end{tabular}

Values are mean \pm SEM of 5 independent experiences $(n=5)$; Aq. Ext.: Aqueous extract; Eth. Ext.: Ethanolic extract; Diabetics without Treat.: Diabetics without Treatment. $\mathrm{K}^{+}$: Potassium ; $\mathrm{Cl}^{-}$: Chloride ; $\mathrm{Na}^{+}$: Sodium ; $\mathrm{Ca}^{2+}$ : Calcium; $\mathrm{Mg}^{2+}$ : Magnesium; $+\mathrm{p}<0.01 ;++\mathrm{p}<0.001 ;{ }^{*} \mathrm{p}<0.05$; ${ }^{* *} \mathrm{p}<0.005$. Results of D14 compared to D0 into the same group. a: $\mathrm{p}<0.05$; et b: $\mathrm{p}<0.01$ results with SPA compared to without SPA, at J14. 


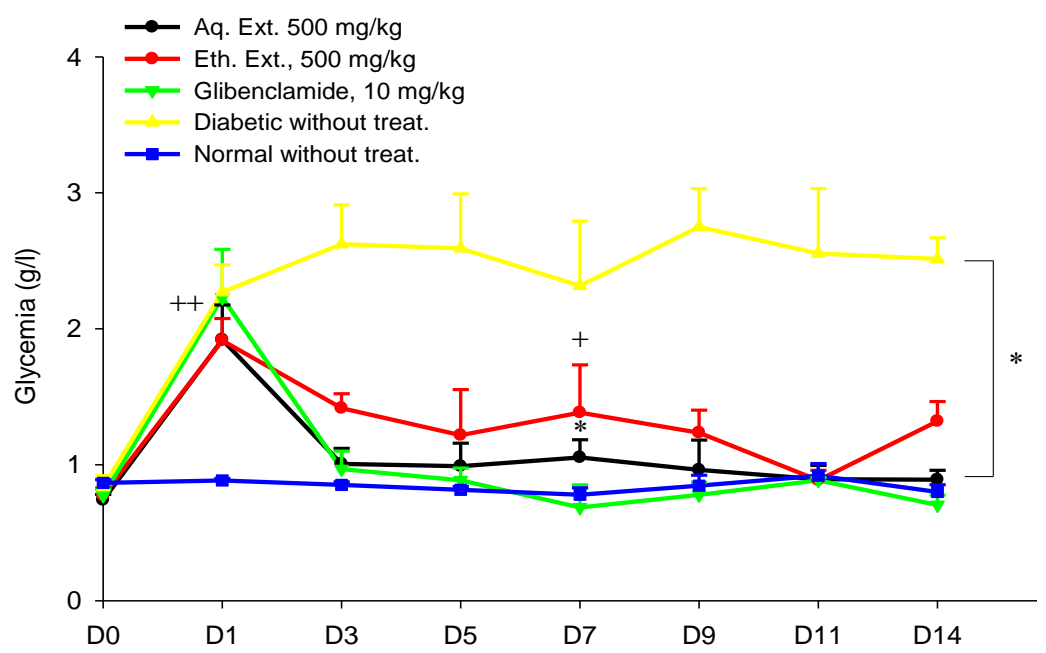

Figure 1:-Blood glucose variation in streptozotocin-induced diabetic rats

Diabetes was induced by administering nicotinamide (NAD) $230 \mathrm{mg} / \mathrm{kg}$ (ip) $15 \mathrm{~min}$ before streptozotocin (STZ) $65 \mathrm{mg} / \mathrm{kg}$ (iv) after $16 \mathrm{~h} \mathrm{fasting}$. Twenty five (25) rats, aged between 8 and 10 weeks and weighing 200 to $250 \mathrm{~g}$ were divided into five (5) groups of 2 females and 3 males each. Seventy two hours later, rats were classified diabetics if glucose level $\geq 175 \mathrm{mg} / \mathrm{dl}$. Group 1 received Glibenclamide $10 \mathrm{mg} / \mathrm{kg}$ bw, groups 2 and 3 received aqueous and ethanolic extract at $500 \mathrm{mg} / \mathrm{kg}$ bw of C. aegyptiaca respectively, group 4 (diabetics without treatment) and group 5 (non diabetics) received only distilled water at $10 \mathrm{ml} / \mathrm{kg}$ bw, once a day during 14 days. Blood parameters were measured before diabetes induction (D0) and at D14. Serum glucose was measured by Glucose Oxidase (GOD-POD) method (ELITech Group, Puteaux, France) according to the manufacturer's instructions. The curves were representative of the mean \pm SEM of 5 independent experiences $(\mathrm{n}=5)$. Aq. Ext., $500 \mathrm{mg} / \mathrm{kg}$ : Aqueous extract $500 \mathrm{mg} / \mathrm{kg}$; Ext. Eth., $500 \mathrm{mg} / \mathrm{kg}$ : Ethanolic extract $500 \mathrm{mg} / \mathrm{kg}$ bw; Glb, $10 \mathrm{mg} / \mathrm{kg}$ : Glibenclamide $10 \mathrm{mg} / \mathrm{kg}$; Diabetic without Trait.: Diabetics without Treatment; Normal without Trait.: Normal without Treatment. $\mathrm{mg} / \mathrm{kg}$ : Milligramm per kilogramm body weight; g/l: Gramm per liter; *p<0.05; ++p<0.001. D: Day.
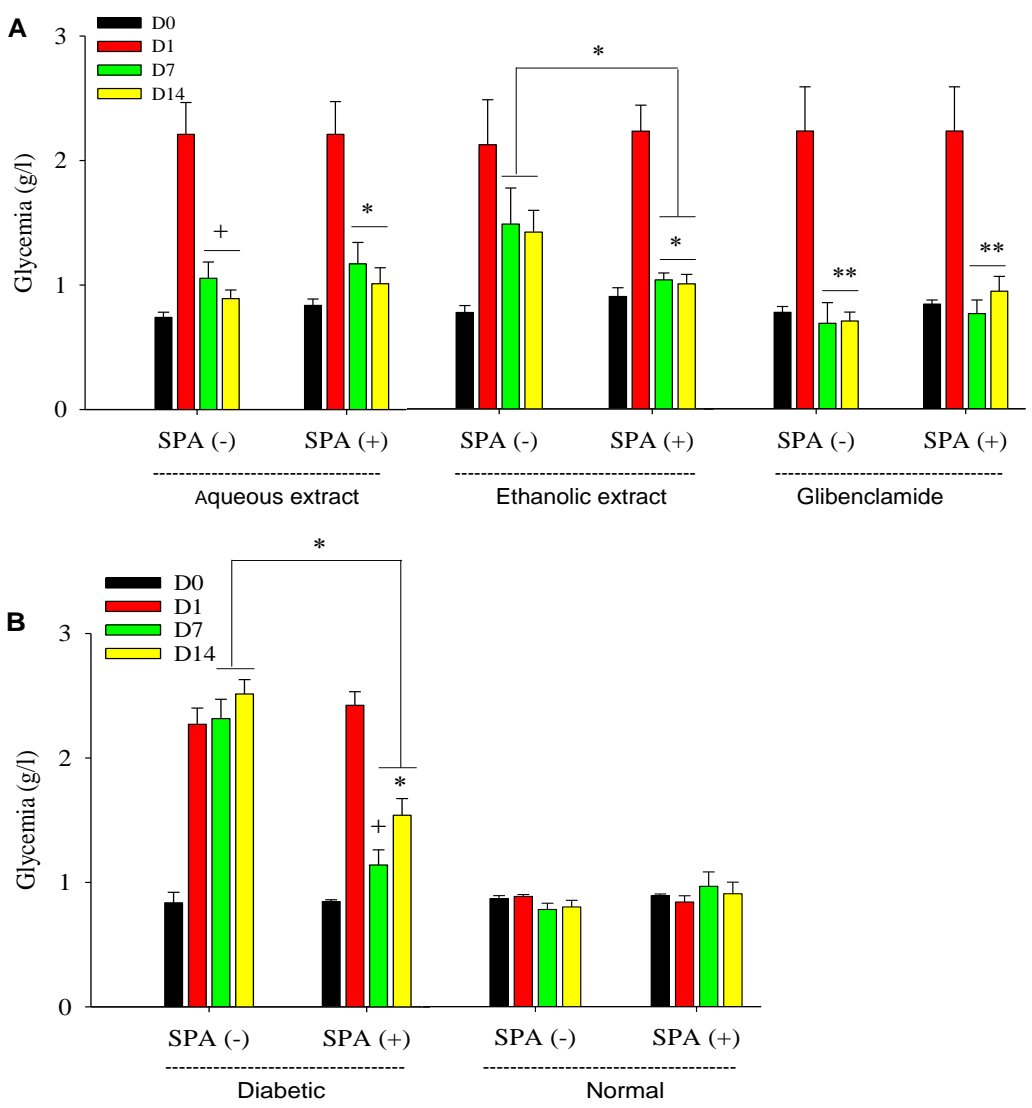

Figure 2:-Blood glucose variation with the streptozotocin-induced diabetic rats submitted to swimming 
Rats were acclimated to the swimming during one week, fifteen minutes per day. Diabetes was induced by administering nicotinamide (NAD) $230 \mathrm{mg} / \mathrm{kg}$ (ip) $15 \mathrm{~min}$ before streptozotocin (STZ) $65 \mathrm{mg} / \mathrm{kg}$ (iv) after $16 \mathrm{~h}$ fasting. Twenty five (25) rats, aged between 8 and 10 weeks and weighing 200 to $250 \mathrm{~g}$ were divided into five (5) groups of 2 females and 3 males each. Seventy two hours later, rats were classified diabetics if glucose level $\geq 175 \mathrm{mg} / \mathrm{dl}$. Group 1 received Glibenclamide $10 \mathrm{mg} / \mathrm{kg}$ bw, groups 2 and 3 received aqueous and ethanolic extract at $500 \mathrm{mg} / \mathrm{kg}$ bw of C. aegyptiaca respectively (Fig. 2A), group 4 (diabetics without treatment) and group 5 (Normal) received only distilled water at $10 \mathrm{ml} / \mathrm{kg} \mathrm{bw}$ (Fig. 2B), once a day during 14 days. Blood parameters were measured before diabetes induction (D0) and at D14. Serum glucose was measured by Glucose Oxidase (GOD-POD) method (ELITech Group, Puteaux, France) according to the manufacturer's instructions. The curves were representative of the mean \pm SEM of 5 independent experiences $(\mathrm{n}=5)$. Aq. Ext.,500 mg/kg: Aqueous extract $500 \mathrm{mg} / \mathrm{kg}$; Ext. Eth., $500 \mathrm{mg} / \mathrm{kg}$ : Ethanolic extract $500 \mathrm{mg} / \mathrm{kg} \mathrm{bw}$; Glb, $10 \mathrm{mg} / \mathrm{kg}$ : Glibenclamide $10 \mathrm{mg} / \mathrm{kg}$; Diabetic without Trait.: Diabetics without Treatment; Normal without Trait.: Normal without Treatment. mg/kg: Milligramm per kilogramm body weight; g/l: Gramm per liter; ${ }^{*} \mathrm{p}<0.05 ; * * \mathrm{p}<0.005 ;+\mathrm{p}<0.01$. D: Day; SPA (-): Without sport and physical activity; SPA (+): With sport and physical activity; D0, D1, D7, D14: Day 0, Day 1, Day 7, Day 14.

\section{References:-}

1. Akakpo, B.H., Akpovi, C.D., Medehouenou, T.C.M., Assogba, F.M., Dansou, P.H., and Gbenou, J.D. (2016): Conyza aegyptiaca (L.) Dryand ex. Aiton extracts exhibite antioxidant activity and prevent hepatic glucose liberation in vitro. Int. J. of Biosci., 9(6): 431-439.

2. Akakpo, B.H., D. Akpovi, C., Ahounou Aïkpé, J.F., Kinsou, L.D.C., Gbénou, D.J., and Dansou, H.P. (2017): Conyza aegyptiaca (L.) Dryand ex. Aiton effect on blood glucose levels in normal albinos rats through oral glucose tolerance test. Int. J. Curr. Res. Chem. Pharm. Sci., 4: 19-26.

3. Akpagana, K., Koumaglo, K.H., Bouche, P.H., and Gbeassor, M. (1996): Un cas de sauvegarde passive d'une espèce utile et en voie de disparition au Togo : Conyza aegyptiaca var. lineariloba. Med. Pharm. Afr., 10: 99102.

4. Akpovi, C.D., Segbo, A.G.J., Medehouenou, T.C.M., Anago, A.A.E., Akakpo, B.H. and Loko, F. (2015): Lipid profile in type 2 diabetic subjects aged 40 years and over living in Benin. Int. J. of Biomed. Res., 6(10): 805810 .

5. Association Canadienne du Diabète. (2008): Lignes directrices de pratique clinique 2008 de l'Association canadienne du Diabète pour la prévention et le traitement du diabète au Canada. Can. J. Diabetes, 32(1):1-239.

6. Dengel, D.R., Galecki, A.T., Hagberg, J.M., and Pratley, R.E. (1998): The independent and combined effects of weight loss and aerobic exercise on blood pressure and oral glucose tolerance in older men. Am. J. Hypertens., 11: 1405-1412.

7. Gbekley, E.H., Karou, D.S., Gnoula, C., Agbodeka, K., Anani, K., Tchadjobo, T., Agbonon, A., Batawila, C., and Simpore, J. (2015): Étude ethnobotanique des plantes utilisées dans le traitement du diabète dans la médecine traditionnelle de la région Maritime du Togo. Pan. Afr. Med. J., 20: 1-16.

8. Gning, S., B., Thiam, M., Fall, F., Ba-Fall, K., Mbaye, P.S., and Fourcade, L. (2007): Diabetes mellitus in subSaharan Africa: epidemiological aspects and management issues. Med. Trop., 67: 607-611.

9. Goldenberg, R., and Punthakee, Z. (2013): Definition, classification and diagnosis of diabetes, prediabetes and metabolic syndrome. Can. J. Diabetes, 37( Suppl 1): S8-11.

10. Grover, J., Yadav, S., and Vats, V. (2002): Medicinal plants of India with anti-diabetic potential. J. Ethnopharmacol., 81: 81-100.

11. Hanan, S.E., and Mona, F.S. (2014): Phytothérapy in diabetes: Review on potential mechanistic perspectives. World J. Diabetes, 5: 176-197.

12. Hussain, A., Claussen, B., Ramachandran, A., and Williams, R. (2007): Prevention of type 2 diabetes: a review. Diabetes Res. Clin. Pract., 76: 317-326.

13. Irwin, M.L., Yasui, Y., Ulrich, C.M., Bowen, D., Rudolph, R.E., Schwartz, R.S., Yukawa, M., Aiello, E., Potter, J.D., and McTiernan, A. (2003): Effect of exercise on total and intra-abdominal body fat in postmenopausal women: a randomized controlled trial. JAMA, 289: 323-330.

14. Kamakura, M., Mitani, N., Fukuda, T., and Fukushima, M. (2001): Antifatigue effect of fresh royal jelly in mice. J. Nutr. Sci. Vitaminol., 47: 394-401.

15. Kelley, D.E., and Goodpaster, B.H. (1999): Effects of physical activity on insulin action and glucose tolerance in obesity. Med Sci Sports Exerc., 31: S619-S623.

16. Kraus, W.E., Houmard, J.A., Duscha, B.D., Knetzger, K.J., Wharton, M.B., McCartney, J.S., Bales, C.W., Henes, S., Samsa, G.P., Otvos, J.D., et al. (2002): Effects of the amount and intensity of exercise on plasma lipoproteins. N. Engl J. Med., 347: 1483-1492.

17. Liamis, G., Liberopoulos, E., Alexandridis, G., Elisaf M. (2012): Hypomagnesemia in a department of internal medicine. Magnes Res., 4: 149-158. 
18. Masiello, P., Broca, C., Gross, R., Roye, M., Manteghetti, M., Hillaire-Buys, D., Novelli, M., and Ribes, G. (1998): Experimental NIDDM: development of a new model in adult rats administered streptozotocin and nicotinamide. Diabetes, 47: 224-229.

19. Matsumoto, K., Ishihara, K., Tanaka, K., Inoue, K., and Fushiki, T. (1996): An adjustable-current swimming pool for the evaluation of endurance capacity of mice. J. Appl. Physiol., 81: 1843-1849.

20. Prashanth, D., Amit, A., Samiulla, D.S., Asha, M.K., and Padmaja, R. (2001): Glucosidase inhibitory activity of Mangifera indica bark. Fitoterapia, 72: 686-688.

21. Rakieten, N., Rakieten, M.L., and Nadkarni, M.V. (1963): Studies on the diabetogenic action of streptozotocin (NSC-37917). Cancer Chemother. Rep., 29: 91-98.

22. Rice, B., Janssen, I., Hudson, R., and Ross, R. (1999): Effects of aerobic or resistance exercise and/or diet on glucose tolerance and plasma insulin levels in obese men. Diabetes Care, 22: 684-691.

23. Ross, R., Dagnone, D., Jones, J.P., Smith, H., Paddags, A., Hudson, R., and Janssen, I. (2000): Reduction in obesity and related comorbid conditions after diet-induced weight loss or exercise-induced weight loss in men: a randomized, controlled trial. Ann. Intern. Med., 133: 92-103.

24. Sharma, B., Balomajumder, C., and Roy, P. (2008): Hypoglycemic and hypolipidemic effects of flavonoid rich extract from Eugenia jambolana seeds on streptozotocin induced diabetic rats. Food Chem. Toxicol., 46: 23762383.

25. Snowling NJ, H.WG. (2006): Effets of different modes of exercice training on glucose control and risk factors for complications in type 2 diabetic patients : a meta-analysis. Diabetes Care, 29: 2518-2527.

26. Srinivasan, K., and Ramarao, P. (2007): Animal models in type 2 diabetes research: an overview. Indian J. Med. Res., 125: 451-472.

27. Vogiatzi, G., Tousoulis, D., and Stefanadis, C. (2009): The role of oxidative stress in atherosclerosis. Hellenic. J. Cardiol., 50: 402-409.

28. Vuori, I.M. (2001): Health benefits of physical activity with special reference to interaction with diet. Public Health Nutr., 4: 517-528.

29. World Health Organisation (2016): World report on Diabetes. Geneva (Suisse).

30. Yessoufou, A., Gbenou, J., Grissa, O., Hichami, A., Simonin, A.-M., Tabka, Z., Moudachirou, M., Moutairou, K., and Khan, N.A. (2013): Anti-hyperglycemic effects of three medicinal plants in diabetic pregnancy: modulation of T cell proliferation. BMC Complem. Altern. Med., 13:77-89. 